\title{
Short Communication: Viability and environmental effect to conidial germination of antagonistic fungi that potential as biological control of Colletotrichum gloeosporoides caused antracnose disease on chili
}

\author{
NURBAILIS`, MARTINIUS, VERRY AZNIZA \\ Departement of Plant Protection, Agriculture Faculty, Universitas Andalas. Jl. Raya Unand, Limau Manis, Pauh, Padang 25163, West Sumatra, \\ Indonesia. Tel./fax.: +62-751-72776, ^email: nurbailis@agr.unand.ac.id
}

Manuscript received: 12 March 2018. Revision accepted: 4 May 2018

\begin{abstract}
Authors. 2018. Short Communication: Viability and environmental effect to conidial germination of antagonistic fungi that potential as biological control of Colletotrichum gloeosporoides caused antracnose disease on chili. Biodiversitas 19: 974-977. Some of antagonistic fungi from chili rhizosphere were potential to suppress the growth of colletotrichum gloeosporoides in vitro. This present study was aimed to observe the viability of antagonistic fungi and effect of temperature and ultraviolet light to its conidial germination. We targeted to obtain the isolate with the best viability and high resistance to temperature and ultraviolet changes. The experiment used a completely randomized design consisted of nine treatments and four replication. The treatment were nine of antagonistic fungi isolates from chili rhizosphere that consisted of two genera, Trichoderma and Paecilomyces, each comprised four isolates and unidentified isolate ( $\mathrm{X}$ isolate). These four isolates were considered as replication for observation. The observed parameters observe included the width of colony, density of conidia, germination of conidia, effect of temperature and ultraviolet light changes to conidial germination. The results showed that antagonistic fungi from the genus Trichoderma had the best viability (the width of colony $=39.68-56.92 \mathrm{~cm}^{2}$, density of conidia $40.50-57.50 \times 10^{9}$ conidia $/ \mathrm{mL}$ and germination of conidia $>80 \%$ ) and highest resistance to temperature and ultraviolet changes compared with the other fungi used in this study.
\end{abstract}

Keywords: Antagonistic fungi, conidia, Trichoderma, temperature, ultraviolet light

\section{INTRODUCTION}

The anthacnose disease caused by Colletotrichum capsici and Colletotrichum gloesporoides is one of the important and disastrous diseases in chili (Montri et al. 2009; Sharma and Kulshrestha 2015). This pathogen can infect the mature and immature fruit of pepper that caused the great loss of production (Robert et al, 2015). The Colletotrichum pathogen is difficult to control since it is seed-borne disease and it has high genetic diversity (Than et al. 2008)

Generally, farmers control the anthracnose disease by using fungicides. However, continue use of fungicides cause negative impacts on the environment and consumers. Thus, it is necessary to discover alternative controls to this pathogen that are environmentally friendly by using fungi that are antagonistic to pathogens as a biological control. According to Begum et al. (2008), some fungi and bacteria derived from soybean seeds have the potential to inhibit the growth of $C$. truncatum which causes anthracnose in soybean. Such isolates with high ability are $T$ virens isolates UPM 23, T. harzianum isolates UPM 40 and Pseudomonas aeruginosa isolate 13B8. Ghosh and Chakraborty (2012) reported that five isolates of $T$. viride isolates were able to suppress the growth of $C$. gleosporoides fungi that caused anthracnose in Roulvolfia serpentine plants. Another study by Nurbailis and Martinius (2014) found that 9 of 52 fungi isolates originated from chili rhizosphere, potentially inhibited the growth of $C$. gloeosporoides that caused anthracnose in chili. Of the 9 isolates, 4 were Trichoderma, 4 were Paecilomyces isolates and one unidentified.

Trichoderma are free-living fungi, usually found in soil and root ecosystems. They are opportunistic, avirulent, plant symbionts, as well as being parasites to plant pathogen of fungi (Harman et al. 2004). In an artificial medium (Potato Dextrosa Agar) Trichoderma grow well within 3 days as fungal colony that can reach $9 \mathrm{~cm}$ diameter of petri dish (Shahid et al. 2013). Trichoderma spp. grow best in a temperature range of $25^{\circ} \mathrm{C}$ to $30^{\circ} \mathrm{C}$ (Singh et al. 2014).

Paecilomyces are cosmopolite fungi living in the soil, rotting plant debris and food product. Liang et al. (2005) reported that Paecilomyces spp. grow slowly with the growth rate ranged from $0.6-6.5 \mathrm{~cm}$ during 14 days. Paecilomyces gunnii have even much slower with the growth was only 2.2-2.8 cm on Czapek medium. Kiewnick (2006). Paecilomyces lilacinus can grow well with temperature between 24 and $30^{\circ} \mathrm{C}$, but not above $36^{\circ} \mathrm{C}$, the conidia germinated at temperature between 28 and $30^{\circ} \mathrm{C}$.

Conidial germination of various antagonistic fungi is strongly influenced by changes in temperature and ultraviolet light exposure. According to Poosapati et al. (2014) conidia of Trichoderma spp from different agro climatic zone of India reduced their ability to germinate at 
temperature $37^{\circ} \mathrm{C}$ except for $T$. asperellum-TaDOR673. This fungi isolate was highly tolerant at high temperature $52^{\circ} \mathrm{C}$, and was still able to produce fairly dense conidial and higher conidial germination compared to other isolate. The result of screened in vitro and in vivo indicated $T$. asperellum-TaDOR673 effectively for controlling the collar rot disease caused by Sclerotium rolfsii in groundnut.

Gupta and Sharma (2013), reported that generally $T$. harzianum can grow well at $25-30^{\circ} \mathrm{C}$ on Potato Dextrosa Agar. The growth will be reduced when the temperature increase above $37^{\circ} \mathrm{C}$ and no growth was observed at $45^{\circ} \mathrm{C}$ six days after inoculation. Jamali and Banihashemi (2012) stated that there is a species of Paecilomyces fungi that is thermophilic, and is still able to grow well above $50^{\circ} \mathrm{C}$.

Despite of temperature, ultraviolet light also influence the germination of conidia. Menetrez et al. (2010) reported that the ultraviolet radiation could cause cell mortality and genetic mutation when the fungi are exposed under ultraviolet light within a certain period. Asthana and Tuveson (1992) stated that the ultraviolet-B irradiation components on the sun could damage protein and DNA of the pathogenic fungi, thus affecting the physiological activity and metabolic response. Rodrigues et al. (2016) reported that 5 minutes exposure to ultraviolet can reduce conidial germination of of Beauveria bassiana from $95 \%$ to $52 \%$ and from $96 \%$ to $54 \%$ for $M$. anisopliae.

The objective of this study was to determine the viability and the effect of temperature and ultraviolet light towards conidial germination of antagonistic fungi indigenous to chili rhizosphere. This fungi has the potential in suppressing the growth of $C$. gloeosporiodies that caused anthracnose disease on chili

\section{MATERIALS AND METHODS}

\section{Design}

The study involved two objectives, i.e. testing the viability of antagonistic fungi that have the potential for inhibiting the growth of $C$. gloeosporoides that causes anthracnose disease in chili; and to assess the effect of temperature and ultraviolet rays on the conidial germination of this antagonistic fungi. This study used Completely Randomized Design (CRD) with 9 treatments and 4 replications. The treatments were various isolates of antagonistic fungi: Trichoderma spp. (sp.1, sp.2, sp.3 and sp.4) Paecilomyces spp. (sp.1, sp.2, sp.3 and sp.4) and isolate $\mathrm{X}$. Each of isolate made four replication for observation.

\section{Rejuvenation and propagation of antagonistic fungi isolate}

Rejuvenation of antagonistic fungal isolates was performed by reproducing the fungal isolates on PDA medium. The reproduced antagonistic fungi in the PDA medium were extracted using a $0.5 \mathrm{~cm}$ diameter borer core and transferred into a Petri dish which contains a PDA medium, then incubated for 7 days.

\section{The width of colony}

The coverage test of colonial growth was performed by extracting a piece of Fungi mycelium which has been reproduced in PDA medium using $0.5 \mathrm{~cm}$ diameter borer corer and then grown into Petri dish which contained PDA medium and incubated at room temperature. The each Fungi colonial coverage was measured from day 2 after inoculation until the culture was 14 days old.

\section{Conidial germination test}

Conidial germination test was performed by preparing a $1 \mathrm{~cm}^{2}$ size and $2 \mathrm{~mm}$ thick of PDA medium that was located on a sterile object glass. $10 \mu \mathrm{l}$ of conidial suspension containing $10^{6}$ conidia $/ \mathrm{mL}$ was dripped. The object glass was inserted into a sterile Petri dish containing a moistened filter paper and incubated at room temperature for 24 hours.

\section{Conidial density}

Conidial density of each Antagonistic fungal isolate was performed by preparing a conidial suspension with concentration of $10^{6}$ conidia $/ \mathrm{mL} .0 .1 \mathrm{~mL}$, each isolate was inserted in a Petri dish containing PDA media and incubated at $28^{\circ} \mathrm{C}$. After 14 days, the cultures were inserted into Erlenmeyer and added with $50 \mathrm{~mL}$ of sterile distilled water. The cultures were then homogenized in a shaker for 5 minutes and filtered using Whatman-paper no. 4. The filtered conidias were put into a test tube and added with 9 $\mathrm{mL}$ sterile distilled water and diluted to $10^{-4}$. The conidial concentration of the suspension was calculated using a haemocytometer.

\section{Conidial sensitivity to temperature}

The sensitivity test of conidial fungal isolate towards the temperature change was performed by extracting a conidial suspension from each antagonistic fungal isolate at a concentration of $10^{6}$ conidia $/ \mathrm{mL}$, and then inserted into a $5 \mathrm{~mL}$ reaction tube. Each isolate was incubated in a water bath using different temperatures $\left(10^{\circ}, 30^{\circ}\right.$, and $50^{\circ} \mathrm{C}$; ) and a control for 30 minutes. Calculation of the conidial germination was performed using the same method as germination test of conidial antagonistic fungi.

\section{Conidial sensitivity to ultraviolet light}

Sensitivity test of conidial antagonistic fungi against UV light was performed using: pure culture aged 14 days in a petri dish that was placed on open space to be exposed to direct sunlight. The exposure to the UV light was performed for 0,30 , and 60 minutes. The germination of conidial antagonistic aungi was calculated using the same method as germination test experiment.

\section{RESULTS AND DISCUSSION}

\section{Viability of antagonistic fungi}

The viability of various antagonistic fungi used in this study varied significantly between isolates, while conidial germination did not vary significantly between isolates (Table 1). 
The largest area of antagonistic fungal colonies was found in Trichoderma sp.2 isolate, with colony area of $56.92 \mathrm{~cm}^{2}$ and the smallest was found in Paecilomyces sp. 1 isolate with $11.78 \mathrm{~cm} 2$ colony area (Table 1). The highest density of conidial was found in the Trichoderma sp. 3 isolate as $57.5 \times 109$ conidia/mL and the smallest was found in Paecilomyces sp.4 as $26.50 \times 109$ conidia $/ \mathrm{mL}$. Isolate $\mathrm{X}$ did not form conidial (Table 1). In general, conidial germination of various antagonistic fungi was relatively high, as more than $80 \%$ and did not vary significantly between isolates.

\section{Temperature effect to germination of antagonistic fungal conidia}

The effect of temperature change towards germination of conidial of antagonistic fungi varied significantly between isolates (Table 2). For some isolates such as Paecilomyces sp.4, Paecilomyces sp.1, Trichoderma sp.4, the germination of conidial at $10^{\circ} \mathrm{C}$ survived above $60 \%$, while isolates Paecilomyces sp.2, Trichoderma sp.3, Trichoderma sp.2 and Paecilomyces sp. 3 only survived for $40-60 \%$. At a temperature of $30^{\circ} \mathrm{C}$, conidial germination of indigenous rhizosphere antagonistic fungi was normal and the lowest conidial germination was found in Paecilomyces sp. 1 isolate $(72 \%)$. In general, at a temperature of $50^{\circ} \mathrm{C}$, the germination of conidial of antagonistic fungal was decreases. Two Trichoderma isolates which were still able to germinate well were Trichoderma sp.1 (98.25\%) and Trichoderma sp.2 (79.50\%) (Table 2).

\section{The effect of ultraviolet light towards the germination of antagonistic fungal conidia}

The duration of UV light exposure to the antagonistic fungi tested in this study had significantly different effects on germination of the conidial (Table 3). The highest germination of conidial was observed at 30 minutes UV exposure was recorded in Trichoderma sp.2 isolate (94.5\%), and the lowest was in Paecilomyces sp. 2 isolate $(24 \%)$. Generally the germination of the conidia was decreased at 60 min UV exposure except for Trichoderma sp. 2 was still germinated highly $(84.25 \%)$.

Table 1. The widht of colony, conidial density and germination of several antagonistic fungi from chili rhizosphere

\begin{tabular}{|c|c|c|c|}
\hline \multirow[b]{2}{*}{$\begin{array}{l}\text { Antagonistic fungi } \\
\text { isolates }\end{array}$} & \multicolumn{3}{|c|}{ Viability of several antagonistic fungi } \\
\hline & $\begin{array}{c}\text { Coloni } \\
\text { coverege }\left(\mathrm{cm}^{2}\right)\end{array}$ & $\begin{array}{c}\text { Density of } \\
\text { conidia } \\
\left(\times 10^{9} \text { con. } / \mathrm{mL}\right)\end{array}$ & $\begin{array}{c}\text { Germination } \\
\text { of conidia } \\
(\%)\end{array}$ \\
\hline Trichoderma sp.3 & $56.92 \mathrm{a}$ & $57.50 \mathrm{a}$ & $86.50 \mathrm{a}$ \\
\hline Trichoderma sp.1 & $56.77 \mathrm{a}$ & $40.50 \mathrm{abc}$ & $90.50 \mathrm{a}$ \\
\hline Trichoderma sp.4 & $48.77 \mathrm{ab}$ & $52.00 \mathrm{ab}$ & $100.00 \mathrm{a}$ \\
\hline Trichoderma sp. 2 & $39.68 \mathrm{bc}$ & $44.50 \mathrm{abc}$ & $100.00 \mathrm{a}$ \\
\hline Paecilomyces sp.2 & $38.69 \mathrm{bc}$ & $36.75 \mathrm{abc}$ & $100.00 \mathrm{a}$ \\
\hline Isolate $\mathrm{X}$ & $36.83 \mathrm{bc}$ & - & - \\
\hline Paecilomyces sp.3 & $28.87 \mathrm{c}$ & $27.00 \mathrm{bc}$ & $100.00 \mathrm{a}$ \\
\hline Paecilomyces sp.4 & $25.46 \mathrm{~cd}$ & $26.50 \mathrm{c}$ & $100.00 \mathrm{a}$ \\
\hline Paecilomyces sp 1 & $11.78 \mathrm{~d}$ & $28.50 \mathrm{bc}$ & $100.00 \mathrm{a}$ \\
\hline
\end{tabular}

Note: The figures in the column followed by the same lowercase letter are not significantly different according to DNMRT 5\%
Table 2. Effect of temperature to germination of antagonistic fungal conidia

\begin{tabular}{lcccc}
\hline \multirow{2}{*}{$\begin{array}{l}\text { Antagonistic fungi } \\
\text { isolates }\end{array}$} & \multicolumn{5}{c}{$\begin{array}{c}\text { Percentage of germination of conidia (\%) } \\
\text { at various temperature }\left({ }^{\circ} \mathbf{C}\right)\end{array}$} \\
\cline { 2 - 5 } & $\begin{array}{c}\text { Room } \\
\text { temp. (27) }\end{array}$ & $\mathbf{1 0}$ & $\mathbf{3 0}$ & $\mathbf{5 0}$ \\
\hline & & & & \\
Trichoderma sp.4 & $100 \mathrm{a}$ & $76.75 \mathrm{a}$ & $100 \mathrm{a}$ & $58.50 \mathrm{abc}$ \\
Trichoderma sp. 2 & $100 \mathrm{a}$ & $60.00 \mathrm{ab}$ & $96.75 \mathrm{a}$ & $79.50 \mathrm{abc}$ \\
Pecilomyces $\mathrm{sp} .4$ & $100 \mathrm{a}$ & $40.50 \mathrm{~b}$ & $95.00 \mathrm{a}$ & $46.75 \mathrm{bc}$ \\
Paecilomyces $\mathrm{sp} .2$ & $100 \mathrm{a}$ & $56.25 \mathrm{ab}$ & $100 \mathrm{a}$ & $59.00 \mathrm{abc}$ \\
Paecilomyces $\mathrm{sp} .1$ & $100 \mathrm{a}$ & $55.50 \mathrm{ab}$ & $73.25 \mathrm{~b}$ & $38.75 \mathrm{c}$ \\
Paecilomyces $\mathrm{sp} .3$ & $100 \mathrm{a}$ & $49.25 \mathrm{ab}$ & $100 \mathrm{a}$ & $47.75 \mathrm{bc}$ \\
Trichoderma sp.1 & $90.5 \mathrm{a}$ & $65.00 \mathrm{ab}$ & $97.50 \mathrm{a}$ & $98.25 \mathrm{a}$ \\
Trichoderma sp.3 & $86.5 \mathrm{a}$ & $65.00 \mathrm{ab}$ & $100 \mathrm{a}$ & $81.50 \mathrm{ab}$ \\
Isolat X & - & - & - & - \\
& & & &
\end{tabular}

Note: The figures in the column followed by the same lowercase letter are not significantly different according to DNMRT 5\%

Table 3. Effect of ultraviolet light to germination of antagonistic fungal conidia

\begin{tabular}{llll}
\hline \multirow{2}{*}{$\begin{array}{l}\text { Antagonistic fungi } \\
\text { isolates }\end{array}$} & $\begin{array}{l}\text { Percentage of germination of conidia } \\
\text { (\%) at different duration of UV light } \\
\text { exposure (minute) }\end{array}$ \\
\cline { 2 - 4 } & \multicolumn{4}{c}{$\mathbf{3 0}$} & $\mathbf{6 0}$ \\
\hline & & & \\
Trichoderma sp.4 & $100.00 \mathrm{a}$ & $81.25 \mathrm{a}$ & $69.50 \mathrm{ab}$ \\
Trichoderma sp. 2 & $100.00 \mathrm{a}$ & $94.50 \mathrm{a}$ & $84.25 \mathrm{a}$ \\
Pecilomyces sp.4 & $100.00 \mathrm{a}$ & $24.00 \mathrm{c}$ & $73.00 \mathrm{a}$ \\
Paecilomyces sp. 2 & $100.00 \mathrm{a}$ & $76.00 \mathrm{a}$ & $15.00 \mathrm{~b}$ \\
Paecilomyces sp.1 & $100.00 \mathrm{a}$ & $37.50 \mathrm{bc}$ & $56.00 \mathrm{ab}$ \\
Paecilomyces sp.3 & $100.00 \mathrm{a}$ & $42.00 \mathrm{bc}$ & $37.25 \mathrm{ab}$ \\
Trichoderma sp.1 & $90.50 \mathrm{a}$ & $62.75 \mathrm{ab}$ & $53.25 \mathrm{ab}$ \\
Trichoderma sp. 3 & $86.50 \mathrm{a}$ & $78.50 \mathrm{a}$ & $75.00 \mathrm{a}$ \\
Isolat X & - & - & -
\end{tabular}

Note: The figures in the column followed by the same lowercase letter are not significantly different according to DNMRT 5\%

\section{Discussion}

The Trichoderma genus exhibits faster growth and higher conidial density than the Paecilomyces genus. This genus is one of the soil fungi that has a variety of habitats and is highly competitive against other saprophytic fungi. According to Harman et al. (2004), Trichoderma are cosmopolite, usually found in soil and root ecosystems. They are opportunistic, avirulent, plant symbionts, as well as being parasites to plant pathogen of fungi. On the second day after incubation, the colour of Trichoderma colony on PDA medium was white because of its mycelium. On the third day, then the colour was turning to green, due to the formation of conidial. According to Shahid et al. (2013), the growth of Trichoderma fungal colony isolates can fill the $9 \mathrm{~cm}$ diameter petri dish within 3 days. This genus produced conidial that are green, green, greenish yellow and dark green and concentric conidia. 
The Paecilomyces is a genus of fungi that has slow growth rate and low conidial density. The Paecilomyces genus growth on PDA medium can fill the $9 \mathrm{~cm}$ diameter petri dish on 17 th day and produced low conidial density. According to Liang et al. (2005) the growth of Paecilomyces spp. fungi ranged from $0.6-6.5 \mathrm{~cm}$ for 14 days, even $P$. gunnii growth was very slow accounted only for 2.2-2.8 cm on Czapek Agar medium.

In general, the germination of antagonistic conidial fungi at room temperature $30^{\circ} \mathrm{C}$ was quite high with more than $80 \%$. High germination is essential for the growth and development of fungi as a biological agent. Shahid et al. (2013) reported that Trichoderma grow optimally and produces a high conidial at $25-30^{\circ} \mathrm{C}$. Trichoderma sp. 1 and Trichoderma sp. 3 isolates were able to germinate well at $50^{\circ} \mathrm{C}$ with conidial germination of $98.25 \%$ and $81.50 \%$ respectively. This indicates that Trichoderma was able to germinate above the optimum temperature. The results of research by Poosapati et al. (2014) showed that the Trichoderma asperellum TaDOR673 fungi isolate was highly tolerant to $52^{\circ} \mathrm{C}$ high temperature, and the fungi was still able to produce fairly dense conidial and higher conidial germination compared to other isolates.

One of Paecilomyces isolates that were capable of germinating at temperature above $50^{\circ} \mathrm{C}$ was Paecilomyces sp.1 isolate, thus resistant to high temperatures. Jamali and Banihashemi (2012) stated that $P$. crustaceus and $P$. variotii are thermophilic fungi that could grow well at high temperatures of $50^{\circ} \mathrm{C}$ and $60^{\circ} \mathrm{C}$.

The exposure towards ultraviolet irradiation on the indigenous rhizosphere antagonistic fungi has an effect to its conidial germination. The longer the irradiation time would decreased the conidial germination. The decrease in germination may caused by the conidial cell damage. According to Menetrez et al. (2010), the UV radiation could cause cell mortality and genetic mutation when the fungi are exposed under UV light within a certain period of time. According to Asthana and Tuveson (1992) the UV-B irradiation components on the sun could lead into protein and DNA damage of the pathogenic fungi, thus affecting the physiological activity and metabolic response of the organism.

The antagonistic fungi from the genus Trichoderma genus had the best viability (the width of colony $=39.68$ $56.92 \mathrm{~cm}^{2}$, density of conidia $40.50-57.50 \times 10^{9}$ conidia/mL and germination of conidia $>80 \%$ ) and highest resistance to temperature and ultraviolet changes compared with the other fungi used in this study. The Trichoderma isolates potential to aplicate to chili fruit for controlling antracnose disease.

\section{REFERENCES}

Asthana A, Tuveson RW. 1992. Effects of UV and phototoxins on selected fungal pathogens of citrus. Intl J Plant Sci 153: 442-452.

Begum MM, Sariah M, Abidin MAZ, Puteh AB, Rahman MA. 2008. Antagonistic potential of selected fungal and bacterial biocontrol agents against Colletotrichum truncatum of Soybean Seeds. J Trop Agric Sci 31 (1): 45-53.

Ghosh SK, Chakraborty N. 2012. In vitro biological control of Colletotrichum gloeosporioides, causal organism of anthracnose of sarpagandha (Roulvolfia serpentina). Agric Biol J North Amer 3 (8): 306-310.

Gupta V, Sharma AK. 2013. Assesment of optimum temperature of Trichoderma harzianum by monitoring radial growth and population dynamic in different compost manure and different temperatur. Octa $\mathrm{J}$ Biosci 1 (2): 151-157.

Harman GE, Howell CR, Viterbo A, Chet I, Lorito M. 2004. Trichoderma species-opportuninistic, avirulent plant symbionts. Nature Rev Microbiol 2: 43-56.

Jamali S, Banihashemi Z. 2012. First report of Paecilomyces marquandii from Iran. Rostaniha (Bot J Iran) 13 (2): 207-210.

Kiewnick S. 2006. Effect of temperature on growth, germination, germtube extension and survival of Paecilomyces lilacinus strain 251. Biocontrol Sci Technol 16 (5): 536-546.

Liang ZQ, Han YF, Chu HL, Liu AY. 2005. Studies on the genus Paecilomyces in China. Fungal Div 20: 83-101.

Menetrez MY, Foarde KK, Dean TR, Betancourt DA. 2010. The effectiveness of ultraviolet irradiation on vegetative bacteria and fungi surface contamination Chem Eng J 157: 443-450.

Montri P, Taylor PWJ, Mongkolporn O. 2009. Pathotype of Colletotrichum capsici, the causal agent of chili Antracnose in Thailand. Plant Dis 93(1): 17-20.

Nurbailis, Martinius, Azniza V. 2014. Keanekaragaman jamur saprofit pada rizosfir tanaman cabai sistem konvensional dan organik yang berpotensi mengendalikan Colletotrichum gloeosporoides penyebab penyakit antraknosa pada cabai. Jurnal Hama dan Penyakit Tumbuhan Tropika 14 (1): 16-24. [Indonesian]

Poosapati S, Prasad DR, Navaneetha T, Dinesh KV, Sarada C. 2014. Selection of high temperature and salinity tolerant trichoderma isolates with antagonistic activity againts Sclerotium rolfsii. Springerplus 3: 641. DOI: 10.1186/2193-1801-3-641

Robert PD, Pernezny KL, Kucharek TA. 2015. Antracnose on Pepper in Florida.UF/IFAS Extension University of California.pp-178.

Rodrigues IMW, Forim MR ,Silva MFGF, Fernandes JB, Batista FA. 2016. Effect of Ultraviolet Radiation on Fungi Beauveria bassiana and Metarhizium anisopliae, Pure and Encapsulated, and BioInsecticide Action on Diatraea saccharalis. Adv Entomol 4: 151-162

Shahid M, Srivastava M, Sharma A, Kumar V, Pandey S, Singh A. 2013. morphological, molecular identification and ssr marker analysis of a potential strain of Trichoderma/hypocrea for production of a bioformulation. J Plant Pathol Microbiol 4 (10): 1-7.

Sharma M, Kulshrestha S. 2015. Colletotrichum gloeosporoides: An Antracnose causing pathogen of fruit and vegetable. Biosci Biotechnol Res Asia 12 (2): 1233-1246.

Singh A, Shahid M, Srivastava M, Pandey S, Sharma A, Kumar V. 2014. Optimal physical parameters for growth of Trichoderma species at varying $\mathrm{pH}$, temperature and agitation. Virol Mycol 3 (1): 535-546.

Than PP, Prihastuti H, Phoulivong S, Taylor P, Hyde KD. 2008. Chilli anthracnose disease caused by Colletotrichum species. J Zhejiang Univ Sci B 9 (10): 764-778. 